\title{
Risk and Prevention of Credit Asset Securitization
}

\author{
Gong Yuxia1, a ,Zhang Xin2,b \\ 1,2 Institute of economics and management ,Tianjin university of science and technology, China \\ a: gongyuxia@tust.edu.cn b: ZXXEYONDZX@163.com
}

Keywords: Asset securitization; US subprime crisis; Risk prevention

\begin{abstract}
Securitization first appeared in the United States, and then passed into our country. Although it stopped after the U.S. debt crisis, but forced by the needs of market development, China restarted the pilot in 2012. Asset securitization in China's development time is not long, and how to avoid the risk and make it play a positive effect is an urgent problem to be solved. This paper will combine the revelation of the US subprime crisis, analyze the risks in the course of its operation, and put forward the corresponding preventive mechanism to promote the healthy development of asset securitization in China.
\end{abstract}

\section{Introduction}

As a structural financing product, asset securitization is the most important and fastest growing financial innovation and financial tool in the world financial field in the past 30 years. The operation of securitization of credit assets has a great significance to China's economic development. It can not only improve the capital adequacy ratio of commercial banks, but have important significance for the liquidity of the banks. And it can change the profit model of commercial banks, and disperse the risks so as to promote the further development of China's financial market. But its problems are constantly exposed. In order to make it develop better and serve the economic market of our country, it is the first task to solve the risk problem reasonably.

\section{Brief introduction of credit asset securitization and its development in China}

\subsection{Definition of securitization of credit assets}

From the beginning of the emergence of asset securitization, various experts and scholars have different definitions. Asset securitization has broad and narrow sense. The broad sense of asset securitization was presented by the American scholar Gardener in 1991. Asset securitization is a process or a tool provided by the savers and borrowers to partially or fully match the financial markets. The secular asset securitization refers to the securitization of credit assets. It is an innovative financing technology, the rise of the US residential mortgage securitization, then began to prevail in our country. China's scholars and institutions for the securitization of credit assets under a lot of definitions, including Professor Jiang Jianqing in the "commercial bank securitization," a book is defined as asset securitization refers to a group of poor liquidity loans or other debt instruments To carry out a series of combinations, the packaging, so that the group of assets in the foreseeable future generated by the cash flow is relatively stable, on the basis of the corresponding credit enhancement, improve its credit quality or rating, the technology and process of converting the expected return of the expected cash flow to the bond securities that can flow in the financial market and have a higher credit rating. I think that credit asset securities are securities assets that can have stable liquidity and have future cash flow. After the reorganization of asset pool, and the credit assets as the basis of asset issuance of securities, credit asset securitization is a new financial tool.

There are two types of securitization of credit assets, one is mortgage-backed securitization (MBS) and the other is asset-backed securitization (ABS). In essence, MBS and ABS are only basic assets, not much difference. This innovative financial instruments since its inception, gradually 
more and more countries widely used, and become one of the international financial market trends. Not all assets can be securitized. Securitized credit assets generally have to: first, the future can produce predictable and stable cash flow; second, the relevant historical data of assets easy to obtain; third, the assets of a good historical record. With its extensive use, credit asset securitization theory also tends to mature.

\subsection{The Basic Process of Credit Asset Securitization}

A typical asset securitization process is generally done by seven participating parties (sponsors, SPVs, credit enhancement agencies, credit rating agencies, underwriters, service agencies, and trustees), which are more complex than other assets. (1) the originator chooses the underlying asset to be securitized and builds an asset pool; (2) the establishment of a special purpose vehicle SPV. SPV is a special legal entity set up specifically for asset securitization; (3) transfer assets to SPV; (4) credit enhancement. In order to attract investors and reduce funding costs, securitized products must be extended to increase the credit rating of the securities issued; (5) hire credit rating agencies; (6) designing and selling securities; (7) after the management of cash flows and the successful issuance of securities, SPV receives cash receipts from securities underwriters. Then, according to the agreed price, the promoters shall pay the purchase price of the underlying assets, and the priority shall be paid to the specialized agencies engaged in the purchase.

\subsection{The development of credit asset securitization in China}

2005 was known as "the first year of China's asset securitization." Credit asset securitization and real estate securitization made new progress, so that China began a rapid economic growth trend, and caused widespread concern at home and abroad. April 20, 2005, the People's Bank of China, China Banking Regulatory Commission jointly issued a "credit asset securitization pilot management approach", China's credit asset securitization began to gradually develop to the pilot model was officially launched. In May 2012, the central bank Chinese CBRC, the Ministry of Finance and other departments jointly issued on further standardize the credit asset securitization business pilot ordered to carry out the documents and notice to restart the pilot securitization of credit assets.

Asset securitization is seen as one of the greatest financial innovations of the twentieth Century. It has played a crucial role in the deepening development of American financial markets and is regarded as the prime culprit of the subprime crisis. It is because of this dual characteristics, asset securitization in the domestic pilot has been stop and go. At present, both the system design of some regulators cautious attitude to the asset securitization and asset securitization pilot process, by the U.S. subprime mortgage crisis and the relevant regulatory system reform after the impact of the United states. Analyzing the problems and risks in the implementation of credit asset securitization, it is the first task to propose reasonable solutions to these phenomena. By drawing on the problems existing in the operation of the United States and the deep introspection of the subprime mortgage crisis, and combining with the current market situation in China, relevant laws and regulations are formulated to ensure the healthy development of the securitization of credit assets.

\section{The significance of securitization of credit assets in China}

The implementation of credit asset securitization in China is under the demand of the development of the market. Its implementation will play a positive role in the further development of China's financial market and the improvement of China's financial legal system. After the restart of the pilot program in 2012, its positive role is constantly emerging, and it is an inevitable choice to promote the steady development of all sectors in china.

First of all, the securitization of credit assets is conducive to deepening China's investment and financing system reform. At the same time, asset securitization requires a large number of intermediaries to provide social professional services, so its development will also effectively promote the division of labor and refinement of the entire economy. Second, asset securitization as a structured financing tool for enterprises to provide a new financing channels. It not only helps enterprises to reduce financing costs, improve the debt structure, enhance the value of enterprises, 
but also provide a good financing tool for mergers and acquisitions. Finally, the asset securitization provides a new investment products for investors, not only enrich the asset allocation of ordinary investors, but also can be added for a variety of pension hedging broaden the investment channels, which will help to promote and perfect the guarantee system of our country's socialism.

\section{The Problems in the Development of Credit Asset Securitization in China}

\subsection{The Dilemma of Credit Asset Securitization in China}

The implementation of asset securitization in our country is not very long, and the existing problems are constantly exposed. Although the State Council, the people's Bank, the CBRC, CSRC and other departments have been actively promoting the pilot work of asset securitization, and constantly expand the scope of the pilot, the intention is to use asset securitization to improve the liquidity of credit assets, improve the proportion of direct financing, improve the structure of assets and liabilities of commercial banks, and promote China's economic growth. In fact, asset securitization has been faced with an embarrassing situation in our country. The main reason for this situation is that the policy system and market demand can not be well integrated.

The existing problems are as follows: (1) lack of perfect laws and regulations; (2) the investment groups are mainly commercial banks. At present, the main holders of China's credit asset backed securities are commercial banks, non legal entities, securities companies and policy banks, among which commercial banks account for the highest proportion; (3) bank credit asset securitization administrative approval is more cumbersome and lengthy. China has a strong administrative examination and approval for the management of bank credit asset securitization business.

\subsection{Risk analysis of credit asset securitization in implementation}

Although the financial innovation represented by credit asset securitization has many advantages, we can observe the risks in the process of its implementation. Only effective prevention and avoidance of these risks can fundamentally promote the healthy development of China's financial market and financial system.

The risks of credit asset securitization are as follows: (1) the credit risk produced by the lender. Credit risk refers to the lender in commercial bank loans, not the real situation or commercial bank lending funds can not repay the offer, leading commercial banks have huge losses during normal operation. Such phenomena are closely related to the participants' parties, and any party involved or any breach of the contract may lead to unexpected losses in the transaction process. Such risks not only affect the lender's own credibility, but also bring huge losses to commercial banks. (2) structural risk leads to the payment risk of asset securitization business. Structural risk refers to the failure to realize the authenticity of securitized assets in the process of asset securitization. In this case, SPV due to cash flow to reduce or interrupt the repayment of the crisis, the securitization of the product investors will be extended to the sponsor, the sponsor financial difficulties or even bankruptcy, and then spread to the promoters of the creditors, triggering chain Pay the crisis. (3) credit asset securitization of the moral hazard caused by the debt risk. In China's credit asset securitization practice, the sponsor institutions often play the role of market leader. The growth of the moral hazard of the initiating organization is to reduce the credit conditions, expand the credit business, or pursue a higher risk return, thus reducing the quality of the credit assets of the entire financial system. Once the macroeconomic downturn, the risk of debt outbreak, the financial crisis will be difficult to avoid.

\section{The Countermeasure of Healthy Development of Credit Asset Securitization}

In view of the above problems, the relevant departments of the state must pay attention to the risk of asset securitization business supervision, in order to prevent the accumulation and spread of financial risks. To put forward reasonable and effective countermeasures is the primary task to ensure the sustained and healthy development of credit asset securitization in china.

Specific countermeasures are as follows: 
(1) Improve the laws and regulations of credit asset securitization, and unify the cross market supervision standards. To achieve the quality of China's asset securities over-flight, the securitization of asset securitization is a fundamental requirement. The unified legislation of credit asset securitization business is established by the national legislature, and a unified legal system of asset securitization is established, which includes the unified issuing, listing and trading rules. At the same time, based on the unified legal and legal framework system, to further clarify the credit asset securitization business model of the main regulatory and unified regulatory standards.

(2) Strengthen the credit rating agency supervision, insist on prohibiting the principle of complex securitization. Only continue to strengthen the credit rating agencies conduct supervision, enhance the strength and credibility of the rating agencies, give full play to the credit assessment and risk disclosure, asset securitization can effectively promote sustained and healthy development of the market. In addition, drawing on the experience and lessons of the United States, government must continue to adhere to the principle of prohibiting complex securitization.

(3)Enrich investors and encourage business innovation. Gradually relaxing to the enterprise, individual investors, or qualified foreign investors to participate in the limitation of bank credit asset securitization, in order to satisfy the demands of an increasingly large scale of the issue. At the same time, actively support the banking and other issuers to carry out business innovation, so that the securitization of credit assets will help more industries to solve investment and financing issues, and promote the rapid development of all walks of life.

(4)Guard against moral hazard. In order to guard against moral hazard, we should make a restriction on the asset backed securities initiated by the sponsor institution in light of the actual situation of our country. The sponsoring agency shall jointly hold its own products with other investors, in particular the secondary level securities that should hold high risk levels. To a certain extent, it can solve the moral hazard caused by the adverse selection of the starting agency, and the securitization of the risky and difficult to recognize assets. At the same time, should be limited to the originator of the investment ceiling, for regulatory arbitrage to avoid the use of asset-backed securities and loans regulatory differences, it can also avoid the use of holding the advantages of scale by way of the holders of the general assembly or limit other investors.

(5) Relax institutional investors and strengthen the cultivation of institutional investors. While China's secondary market with a strong administrative color, capital securities investment to a large extent by individual investors to support. Therefore, it is necessary to orderly to relax the scope of institutional investors to encourage and guide more insurance companies, social security funds and other institutional investors to participate in credit asset securitization. In addition, it is possible to allow the credit assets to support the securities in the exchange market with good quality and simple structure. At the same time, efforts should be made to increase the training of investors and improve the ability of investors to analyze and evaluate the risk of various types of securitized products.

\section{Conclusion}

Although the financial crisis on the United States and the world has brought great disaster, it is not possible to abandon the further development of asset securitization because of the impact of the financial crisis. It plays an important role in the economic development of our country. As a result of financial innovation, credit asset securitization forms a unique market trend in the financial industry. This paper argues that to solve these problems and risks need to improve the relevant legal system and the same on the credit asset securitization legislation, perfect and relax the basic assets, relaxation of institutional investors and strengthen the cultivation of institutional investors, strengthening the supervision of credit rating agencies, a series of measures to strengthen the supervision on the financial markets.

With the deepening of the pilot system and the further improvement of the system, China's asset securitization business will change from pilot to normal, from credit assets to more asset projects. Securitization will also seek a suitable future development path between financial regulation and its own advantages. 


\section{References}

[1] Chi Junhui. The present situation and risk prevention analysis of asset securitization in China[J]. International Business Studies.2010,(3):43 49

[2] Qi Xiaowei, Quanhui. The Theory of Securitization of Credit Assets and the Present Situation of China[J]. economy Forum.2014,(3):92 95

[3] Yan Zhuojun. Research on the development of credit asset securitization in China[J]. economy Forum.2015,(23):27

[4] Xiao Yungang. Innovation and supervision of credit asset securitization[J]. special subject.2014,(10):48 49

[5] Xue Hongyan. Reflection on the current system of credit asset securitization -- Based on the experience and lessons of American Credit Asset Securitization[J]. Macroeconomy.2014,(10):24 26

[6] Yan Bingzhu. The practical choice and policy suggestion of commercial banks carrying out credit asset securitization[J]. Financial supervision research.2016,(10):55 68

[7] Chen Zhongyang, Li Lijun. Is there adverse selection in asset securitization -- An Empirical Analysis Based on bank level data in the United States[J]. Financial market.2016,(2):66 74

[8] Feng Shiting. Credit rating system and systematic risk analysis of Asset Securitization[J]. The Theory and Practice of Finance and Economics.2017,(2):140-144

[9] Chen Xiaoxian, Li Duruo. A Study on the Micro Motivation of Securitization of Credit Assets: An Empirical Analysis Based on the Data of China's Commercial Banks[J]. Journal of Shanxi Finance and Economics University.2017,(2):22-34 